\title{
Kinetic and structural characterization of interaction between trypsin and Equisetum arvense extract
}

\author{
[Trypsin ve Equisetum arvense özütü arasındaki etkileşimin kinetik \\ ve yapısal karakterizasyonu]
}

\author{
Mehmet Emin Uslu ${ }^{1}$ \\ Oğuz Bayraktar², \\ Cagatay Ceylan ${ }^{3}$
}

\begin{abstract}
${ }^{1}$ Department of Biotechnology and Bioengineering, İzmir Institute of Technology, İzmir

${ }^{2}$ Department of Chemical Engineering, İzmir Institute of Technology, İzmir ${ }^{3}$ Department of Food Engineering, İzmir Institute of Technology, İzmir
\end{abstract}

\section{Correspondence Address}

[Yazışma Adresi]

\section{Cagatay Ceylan, PhD}

İzmir Yüksek Teknoloji Enstitüsü Gıda Mühendisliği Bölümü, Gülbahçe Köyü, Urla, 35430 İzmir, Türkiye Phone: +902327506328

E-mail: cagatayceylan@iyte.edu.tr

\begin{abstract}
Objective: In this study the inhibitory effect of $E$. arvense extract on trypsin activity and the effect of trypsin on $E$. arvense extract were studied. In addition the nature of the interaction between the extract and trypsin was investigated.

Methods: The inhibitory effect ethanol extract of E. arvense on trypsin activity was determined using trypsin enzyme assay. The structural effects of the extract-trypsin interaction for the extract were analyzed by FTIR. Finally, the HPLC analyses were carried out to analyze the individual components of the extract and the supernatant and soluble precipitate phases.

Results: E. arvense extract was found to decrease total percent activity of trypsin to $5 \%$ in 24 hour at $24{ }^{\circ} \mathrm{C}$. FTIR analyses indicated that the interaction between trypsin and $E$. arvense extract caused changes in the structure and hydrogen bonding behavior and composition of the extract proteins. These interactions also caused the extract lipids to accumulate in the insoluble precipitate phase. Most of the phenolics remained in the supernatant phase enhancing the inactivation of trypsin. However, the precipitated compounds were shown to be of apolar in nature as shown in the HPLC chromatograms.

Conclusion: The methods that were used showed that the high phenolic content of $E$. arvense was the main reason for the inhibition of trypsin enzyme activity by denaturing the enzyme.

Key Words: Trypsin, Equisetum arvense, fourier transform infrared spectroscopy, phenolics

Conflict of Interest: Authors have no conflict of interest.
\end{abstract}

\section{ÖZET}

Amaç: $E$. arvense özütünün tripsin aktivitesi üzerinde ki engelleyici etkisinin ve de tripsinin özüt üzerinde ki etkisi bu çalışmada araştırılmıştır. Bunlara ek olarak ekstrakt ve tripsin arasında ki etkileşimin doğası araştırılmıştır.

Metod: E. arvense bitkisinin etanol özütünün tripsin üzerinde ki engelleyici etkisi tripsin enzim analizi ile belirlenmiştir. Özüt tripsin etkileşiminin özüt üzerinde ki yapısal etkisi FTIR ile analizlenmiştir. Son olarak özütün, süpernetantın ve çözünebilir pelletin özgün bileşenlerin analizi ise HPLC ile belirlenmiştir.

Bulgular: E. arvense özütünün total tripsin aktivitesini $24^{\circ} \mathrm{C}$ sıcaklıkta ve 24 saat sonunda \%5'e kadar düşürdüğü bulunmuştur. Yapılan FTIR analizleri ile tripsin ve E. arvense özütü arasındaki etkileşimin özüt proteinlerinin yapısında, kompozisyonunda ve hidrojen bağı yapma davranışında değişikliklere sebep olduğu anlaşılmıştır. Bu etkileşimler sebebiyle özütte bulunan lipidlerin çözünmez haldeki çökelti fazında toplandığı gözlemlenmiştir. Ayrıca fenolik bileşiklerin çoğunluğunun süpernetant fazında bulunması sebebiyle tripsin inaktivasyonunu arttırdığı anlaşılmıştır. Ancak çökeltide ki bileşiklerin apolar yapıda olduğu HPLC koromotogramları ile gösterilmiştir.

Sonuç: E. arvense bitkisinin sahip olduğu yüksek fenolik madde miktarının tripsin enzim aktivitesinin engellenmesinde enzim denatürasyonunun ana sebep olduğu kullanılan metodlar ile gösterilmiştir.

Anahtar Kelimeler: Tripsin, E. arvense, fourier transform infrared spektroskopisi, fenolikler Çıkar Çatışması: Yazarların çıkar çatışması yoktur. 


\section{Introduction}

Phytochemicals are chemical compounds that are found in plants naturally and provide positive heath effects that are important in biotechnology $[1,2,3]$. Polyphenolic compounds can interact with protein molecules via weak bonds such as hydrogen bonds. They generally form soluble complexes but as the complexes grow larger they become insoluble because the polyphenols form bridges by non-covalent interactions between protein molecules and other complexes [2,4].

One of the plants used in alternative medicine is $E$. arvense, commonly known as field horsetail. This plant can be found in moist areas of northern hemisphere. The plant material contains silicic acid, tartaric acid, methyl esters of protocatechuic and caffeic acids as phenolic acids $[5,6]$. The dominant phenolic compounds are identified as isoquercitrin, apigenin, kaempferol in the plant extract $[7,8]$. In folk medicine horsetail tea is used for cure of edema, kidney and bladder stones, urinary tract infections, the inability to control urination and general disturbances of the kidney and bladder $[9,10]$. Recent investigations have shown that the plant has high antioxidant capacity [11]. Similarly other researchers have indicated that the plant material has anti-inflammatory, anti-microbial, anti-cancer, sedative and anticonvulsant effects [12-15]. Lately $E$. arvense is used in the bathing water for wound healing and blood coagulation in folk medicine $[9,16]$.

Trypsin inhibitors have many benefits for the organisms. Although trypsin inhibitors have many benefits their concentration in the blood should be controlled. An increase in trypsin inhibitor concentration causes hyper secretion of pancreatic enzymes. As a result of this hyper secretion, the pancreas becomes enlarged. This will cause the diseases called hypertrophy and hyperplasia $[17,18]$. For this reason trypsin inhibition potential of foods should be characterized.

In this study the inhibitory effect of $E$. arvense extract on trypsin activity and the effect of trypsin on $E$. arvense extract were investigated. Trypsin enzyme assays were carried out to determine the inhibitory effect $E$. arvense extract on trypsin activity. FTIR analyses were used to study the structural effects of the extract-trypsin interaction for the extract in the both supernatant and precipitate phases formed after bringing these two materials together. Total phenolic content of the extract, the supernatant and soluble precipitate phases were also determined. Finally, the HPLC analyses were carried out to analyze the individual components of the extract and the supernatant and soluble precipitate phases.

\section{Materials and Methods}

\section{Preparation of equisetum arvense extract}

Powdered predried $E$. arvense leaves were mixed with aqueous $70 \%$ ethyl alcohol solution at a solid-liquid ratio of $1: 20$. The dry leafs particles were shaked in the solution for overnight at $300 \mathrm{rpm}$ at $24^{\circ} \mathrm{C}$. After the centrifugation at $2000 \mathrm{xg}$ for 5 minutes the supernatant was collected into $50 \mathrm{ml}$ falcon tubes. The alcohol in the liquid phase was evaporated with a rotary evaporator. The aqueous extract was frozen for 24 hours and then freeze dried in a lyophilizer (Telstar-Cryodos).

\section{Preparation of inhibition solution}

E. arvense extract was dissolved in distilled water to a final concentration of $10 \mathrm{mg} / \mathrm{ml}$. By serial dilutions of stock solution $2 \mathrm{mg} / \mathrm{ml}, 0.2 \mathrm{mg} / \mathrm{ml}$ and $0.02 \mathrm{mg} / \mathrm{ml}$ concentrations were prepared.

\section{Preparation of trypsin solution}

Bovine pancreatic trypsin was purchased from Fluka Analytical (cat.93610) and used without further purification. Lyophilized powder of bovine pancreatic trypsin (Fluka Analytical, USA) was dissolved in $1 \mathrm{mM} \mathrm{HCl}$ to a final concentration of $0.1 \mathrm{mg} / \mathrm{ml}$.

\section{Determination of enzyme kinetics}

Trypsin catalyzes the hydrolysis of N-benzoyl-L-arginine ethyl ester (BAEE) to N-benzoyl-L-arginine (BA) and ethanol. The slope of the absorbance versus time graph was the production rate of $\mathrm{BA}$ at $\mathrm{pH}$ 7.6.The reaction was held in a total volume of $3.2 \mathrm{ml}$ quartz cuvette at $25^{\circ} \mathrm{C}$. The unit of trypsin activity was previously determined as $1 \mu \mathrm{mol} \mathrm{BA}$ produced per minute at $253 \mathrm{~nm}$, at $\mathrm{pH} 7.6$ and $25^{\circ} \mathrm{C}$. The reaction was carried out in $100 \mathrm{mM}$ Tris buffer solution. To determine absorption of blank solution, 3050 $\mu \mathrm{l}$ tris buffer and $150 \mu \mathrm{l}$ of BAEE solution were mixed in a quartz cuvette and the absorbance was read at $253 \mathrm{~nm}$. Enzyme kinetics studies were carried out in $2850 \mu \mathrm{l}$ tris buffer, $150 \mu \mathrm{l}$ BAEE solution and $200 \mu \mathrm{l}$ of $0.05 \mathrm{mg} / \mathrm{ml}$ trypsin mixture solution.

\section{Determination of enzyme inhibition}

Inhibition solution was prepared by mixing various concentration of $E$. arvense extract with $0.5 \mathrm{mg} / \mathrm{ml}$ trypsin in a ratio of $1: 1$. Final concentrations of the compounds in the inhibition solution were $1 \mathrm{mg} / \mathrm{ml}, 0.1 \mathrm{mg} / \mathrm{ml}, 0.01$ $\mathrm{mg} / \mathrm{ml}$ for $E$. arvense extract and $0.05 \mathrm{mg} / \mathrm{ml}$ for trypsin. Incubation of the mixture was done at $+24^{\circ} \mathrm{C}$ and $+4^{\circ} \mathrm{C}$ for minimum 24 hours. In a quartz cuvette, $3050 \mu \mathrm{l}$ tris buffer, $150 \mu \mathrm{l}$ BAEE solutions were mixed and the absorbance values at $258 \mathrm{~nm}$ were read to determine the blank. For inhibition assay, $2850 \mu \mathrm{l}$ tris buffer, $150 \mu \mathrm{l}$ BAEE solution and $200 \mu \mathrm{l}$ trypsin-equisetum arvense mixture were mixed in a quartz cuvette and the enzyme activity assay was carried out.

\section{Processing of the precipitate}

After the inhibition assay, centrifugation was performed at $10,000 \mathrm{xg}$ for 15 minutes. The supernatant was removed and the pellet was dissolved and kept in $1 \mathrm{mM} \mathrm{HCl}$ solution with occasional vortexing. The mixture was centrifuged at 5000xg for $10 \mathrm{~min}$ and the enzyme assay was carried out. 

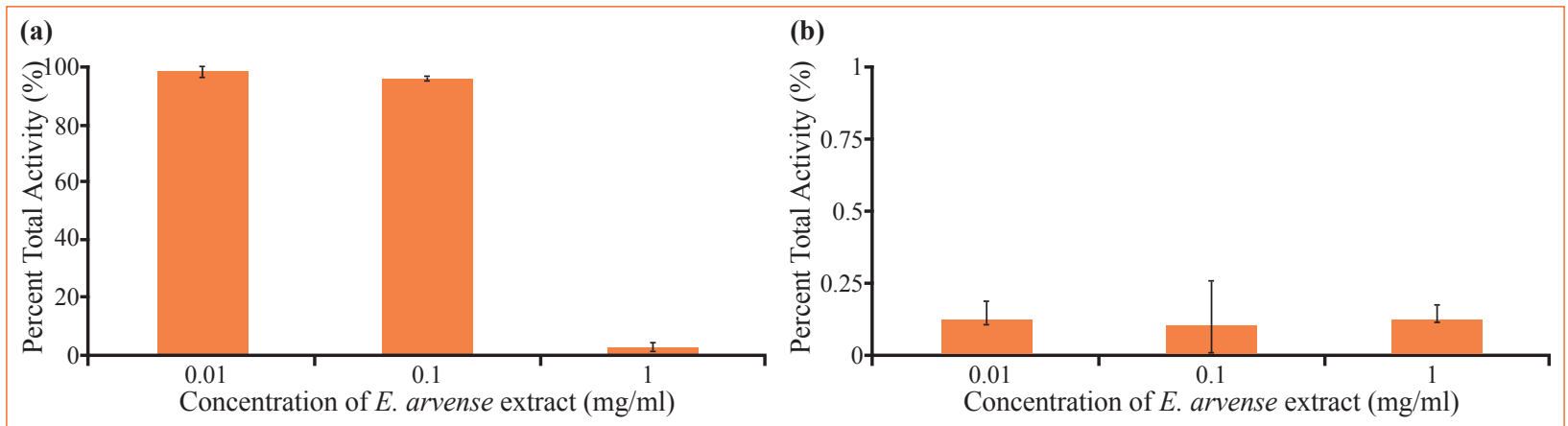

Figure 1. Percent total activity of (a) supernatant (precipitate formed after enzyme extract interaction) and (b) soluble pellet (soluble part of the precipitate formed after enzyme extract interaction) after the interaction of plant extract and trypsin at $24{ }^{\circ} \mathrm{C}$ for $60 \mathrm{hr}$.
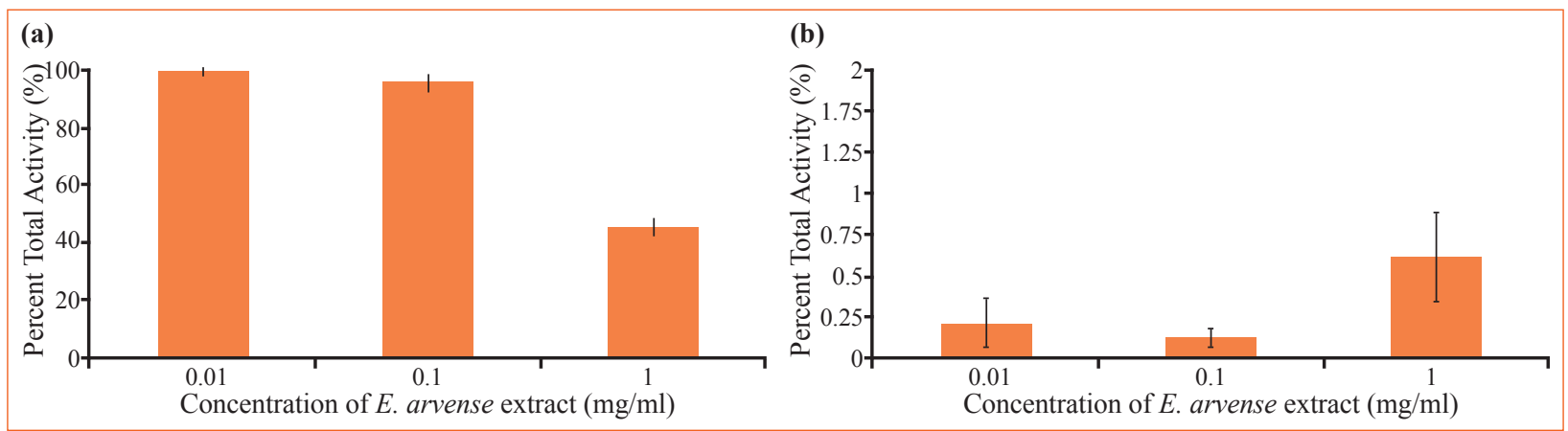

Figure 2. Percent total activity of supernatant (precipitate formed after enzyme extract interaction) (a) and soluble pellet (soluble part of the precipitate formed after enzyme extract interaction) (b) after the interaction of plant extract and trypsin at $4{ }^{\circ} \mathrm{C} \mathrm{for} 60 \mathrm{hr}$.

\section{Sample preparation for FT-IR spectroscopy}

The E. arvense-trypsin mixture was lyophilized in a freeze drier (Telstar-Cryodos) for overnight. The powder was mixed with dry potassium bromide (KBr) (Sigma-Aldrich, USA) in a mortar (at a ratio of 1:100). The mixture was then pressed to $100 \mathrm{~kg} / \mathrm{cm}^{2}$ (1200 psi) for 5 minutes to form a disk.

\section{FTIR spectrum accumulation and data processing}

The spectral analysis was carried out by using a Perkin-Elmer spectrophotometer equipped with MIR TGS detector (Spectrum 100 Instrument, Perkin Elmer Inc., Norwalk, CT, USA). FTIR spectra of the samples were recorded between 4000 and $450 \mathrm{~cm}^{-1}$ region. The background spectrum was subtracted from the spectra of the samples automatically. Spectrum 100 software (Perkin Elmer) was used for all of the data processing. From each sample, at least three different scans, which gave identical spectra, were performed. Smoothing of the spectra was done by using Savitzky-Golay algorithm. Then, the spectra were interactively baselined from two arbitrarily selected points. Finally, the spectra were normalized in specific regions for visual comparison of the samples.

\section{Determination of phenolic content}

Total phenolic content of $E$. arvense extract and trypsin

$E$. arvense mixture was determined by Folin-ciocalteu method. Folin-ciocalteu reagent was prepared by $1: 10$ dilution of stock solution. Sodium carbonate solution of $7 \%$ was prepared in distilled water. Gallic acid was used as standard in the calibration curve. $20 \mu$ of each sample was mixed with $100 \mu \mathrm{l}$ Folin-ciocalteu reagent and incubated for 2.5 minutes. Then $80 \mu$ of sodium carbonate solution was added. The mixture was kept in dark for 1 hour. Samples were subjected to photometric measurement at $725 \mathrm{~nm}$. Results were expressed as $\mathrm{mg}$ of gallic acid equivalents (GAE)/gr dry weight extract.

\section{HPLC analysis}

High-pressure liquid chromatography (HPLC) analysis was modified from the studies of Canadanovic-Brunet et al [13]. HPLC was performed with an Agilent 1100 series device equipped with diode array detector. A reversedphase column, Lichrospher 100- RP 18 with a $5-\mu \mathrm{m}$ particle size (Agilent Technologies, USA), was used at the flow rate of $0.8 \mathrm{~mL} \mathrm{~min}^{-1}$. Mobile phase gradient was performed by varying the proportion of solvent $\mathrm{A}(2.5 \%$ acetic acid) to solvent $\mathrm{B}(100 \%$ acetonitrile) as follows: initial 1\% B; linear gradient to $40 \% \mathrm{~B}$ in 40 minute. The injected sample volume was $20 \mu \mathrm{l}$. All solutions were filtered prior to injection through $0.20 \mu \mathrm{m}$ membrane filters (Millipore, Bedford, MA, USA). The column temperature was $35{ }^{\circ} \mathrm{C}$. The measurements were performed at $280 \mathrm{~nm}$. 


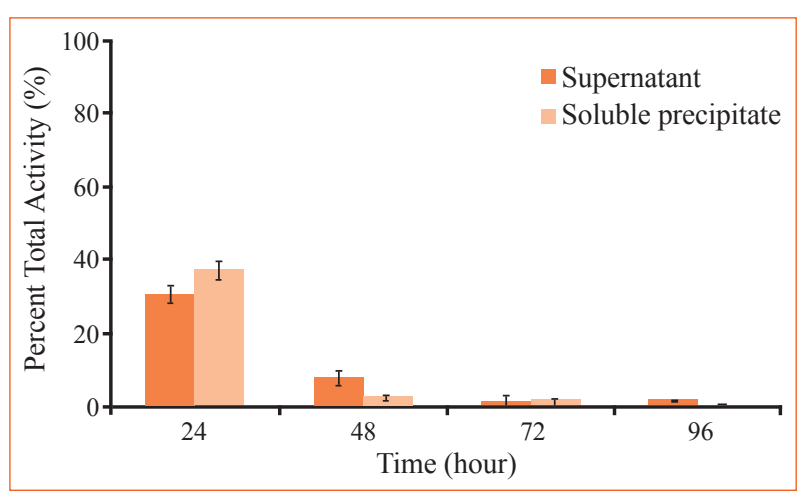

Figure 3. Percent total activity of supernatant and soluble pellet after the interaction of plant extract and trypsin at different time intervals at $24{ }^{\circ} \mathrm{C}$. In the assays $1 \mathrm{mg} / \mathrm{ml}$ E. arvense extract and $0.05 \mathrm{mg} / \mathrm{ml}$ trypsin enzyme were used.

\section{Results and Discussion}

In the present study the interaction between trypsin and $E$. arvense extract was studied using enzyme assays for protein functionality and structural changes.

\section{Trypsin stability studies}

The effect of the interaction on trypsin functionality was tested using trypsin enzyme assay. The percent total activities of both the supernatant (aqueous part formed after enzyme extract interaction) and the soluble pellet (soluble part of the precipitate formed after enzyme extract interaction) at $24^{\circ} \mathrm{C}$ were shown in Figure 1. The solutions with various concentrations of $E$. arvense were mixed with trypsin solutions and incubated for 60 hours at $24^{\circ} \mathrm{C}$. The final concentrations in the mixture were $0.01 ; 0.1$ and $1 \mathrm{mg} / \mathrm{ml}$ for $E$. arvense extract and $0.05 \mathrm{mg} / \mathrm{ml}$ for tryp$\sin$. Trypsin solution with a concentration of $0.05 \mathrm{mg} / \mathrm{ml}$ was also incubated with distilled water at the same conditions in order to use as a control. The original trypsin total activity was taken as $100 \%$ and the other mixtures total activities were calculated compared to two this original trypsin total activity. As shown in Figure 1 the supernatant's percent total activity decreased drastically as the concentration of $E$. arvense extract increased in the mixture. The percent total activity of soluble pellets of mixture, on the other hand were less than 0.2.

In Figure 2 the percent total activity of both supernatant and soluble pellet at $4^{\circ} \mathrm{C}$ was shown. Solutions with various concentrations of $E$. arvense were mixed with trypsin solution and incubated for 60 hours at $4{ }^{\circ} \mathrm{C}$. The final concentrations in the mixture were $0.01 ; 0.1$ and $1 \mathrm{mg} / \mathrm{ml}$ for $E$. arvense extract and $0.05 \mathrm{mg} / \mathrm{ml}$ for trypsin solution. Trypsin solution with a concentration of $0.05 \mathrm{mg} / \mathrm{ml}$ was also incubated with distilled water at the same conditions as a control. As shown in Figure 2, the supernatant percent total activity decreased slightly as the concentration of $E$. arvense extract increased in the mixture. The percent total activity of soluble pellets of mixture, on the other hand were less than $0.75 \%$.
In Figure 3 percent total activity of both supernatant and soluble pellet at $24{ }^{\circ} \mathrm{C}$ were shown. Solution with fixed concentration of $E$. arvense were mixed with trypsin solution and incubated for different time intervals at $24{ }^{\circ} \mathrm{C}$. The final solution concentrations in the mixture were, 1 $\mathrm{mg} / \mathrm{ml}$ for $E$. arvense extract and $0.05 \mathrm{mg} / \mathrm{ml}$ for tryp$\sin$. The time intervals for the incubation were $24,48,72$ and 96 hour. Trypsin solution with a concentration of 0.05 $\mathrm{mg} / \mathrm{ml}$ was also incubated with distilled water at the same conditions as a control. Trypsin total activities for control at different time intervals were taken as $100 \%$ and the other mixtures total activities were calculated depending up this control reference. As shown in Figure 3 the supernatant percent total activity decreased drastically as the incubation time of $E$. arvense and trypsin increased. The same results were seen for the soluble pellet as well.

In all of the experiments a white-colored precipitate phase formation was observed. Therefore the activity loss was studied in both the precipitate and supernatant phases. It is assumed that phenolic compounds in the extract interact with the enzyme and this interaction leads to precipitate formation. As the temperature of incubation decreased to $4{ }^{\circ} \mathrm{C}$ from the room temperature the amount of precipitate that formed due to this interaction also decreased. The results showed that the decrease in the total percent activity was relevant to the amount of precipitate that forms. The experimental result indicated that at higher incubation temperatures the enzyme inactivation kinetics was enhanced in addition to the amount of precipitate formation also increases with increasing temperature. The total percent activity decreased to $5 \%$ at room temperature where as it decreased to $40 \%$ at $4{ }^{\circ} \mathrm{C}$. The amount of precipitate formed at room temperature was more than that at $4{ }^{\circ} \mathrm{C}$.

The results also indicated that in the precipitate phase, almost no enzyme activity was detected. This might be due to the interaction between the enzyme and the compounds present in the extract materials. As the inactivation kinetics results indicated that the total enzyme activity in the supernatant phase decreased over time due to the irreversible loss of enzyme activity. However in the precipitate phase the enzyme activity was much less than that in the supernatant phase (at room temperature total activity of supernatant was $5 \%$ whereas at $4{ }^{\circ} \mathrm{C}$ total activity of soluble precipitate was $0.25 \%$ ).

The phenolic content of E. arvense was reported to contain caffeic acid, syringic acid, ferulic acid, vanilic acid, rutin, apigenin, epicatechin and kaempferol [13]. Interaction of these phenolics with several proteins has been demonstrated. The interaction between caffeic acid and human serum albumin was demonstrated [19]. Investigations on rutin revealed that rutin could bind to trypsin enzyme via hydrophobic interactions and it could also bind to plasma proteins. As a result of this binding, antioxidant capacity of rutin was reported to decrease drastically $[20,21]$. Kaempferol was also shown to bind to bovine 


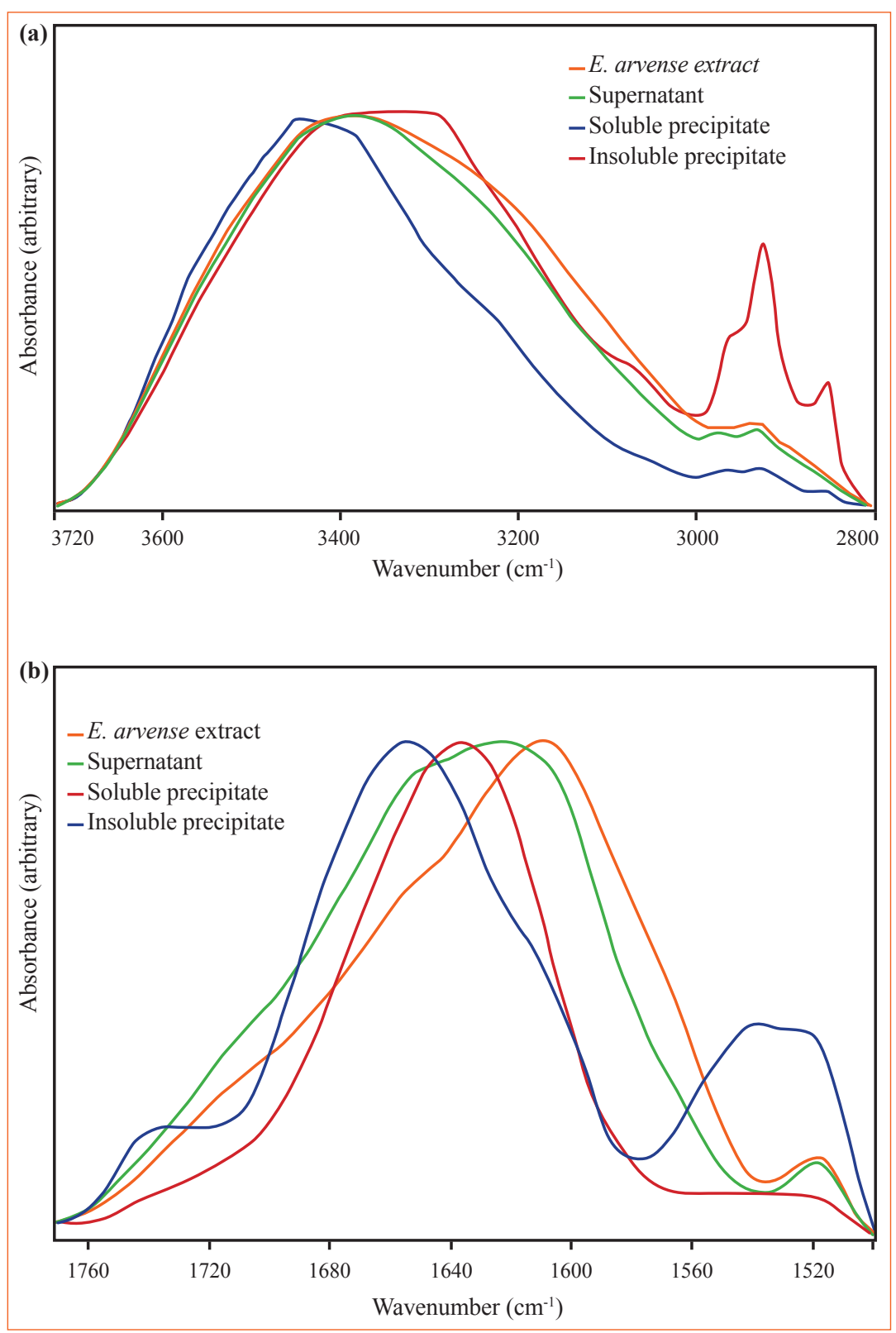

Figure 4. The FTIR analyses of the E. arvense extract and trypsin mixture in the wavenumber ranges of (a) $3720-2800 \mathrm{~cm}^{-1}$ and (b) $1780-1500 \mathrm{~cm}^{-1}$.

serum albumin strongly by hydrophobic interactions and this resulted in changes in secondary structure of protein [22]. The enhanced enzyme activity due the higher temperatures should also increase the amount of precipitate formed. Since it was known that the hydrophobic interactions increased with temperature [23], the results can be explained in the light of hydrophobic interactions between flavonoids in the plant extract and the enzyme, causing more protein inactivation and enhanced precipitate formation as well. Rawel et al. (2002) [24] showed that the phenolic compounds could interact with soy proteins and change their structure by increasing hydroxyl substituents. Their study also showed that these interactions could occur at temperatures as low as $4{ }^{\circ} \mathrm{C}$. The phenolic compounds they studied were caffeic acid, kaempferol, quercetin and apigenin. They found that these substances had high affinity to proteins. As a result of this interaction these compounds were found to form precipitates [24].

The phenolic groups that were found in plant extract can form hydrogen bonds with the polar groups (i.e. amide, guanidine, peptide, amino and carboxyl groups) of protein or the hydrophobic amino acid such as proline, tyrosine and phenylalanine can interact and bind strongly to the polyphenolic substances $[25,26]$.

It was also reported that not only hydrogen bonding but also hydrophobic interactions between enzyme and polyphenols could cause enzyme inactivation. Flavonoids especially kaempferol, were found to have inhibitory effects on trypsin as a result of their hydroxyl groups [27]. In 

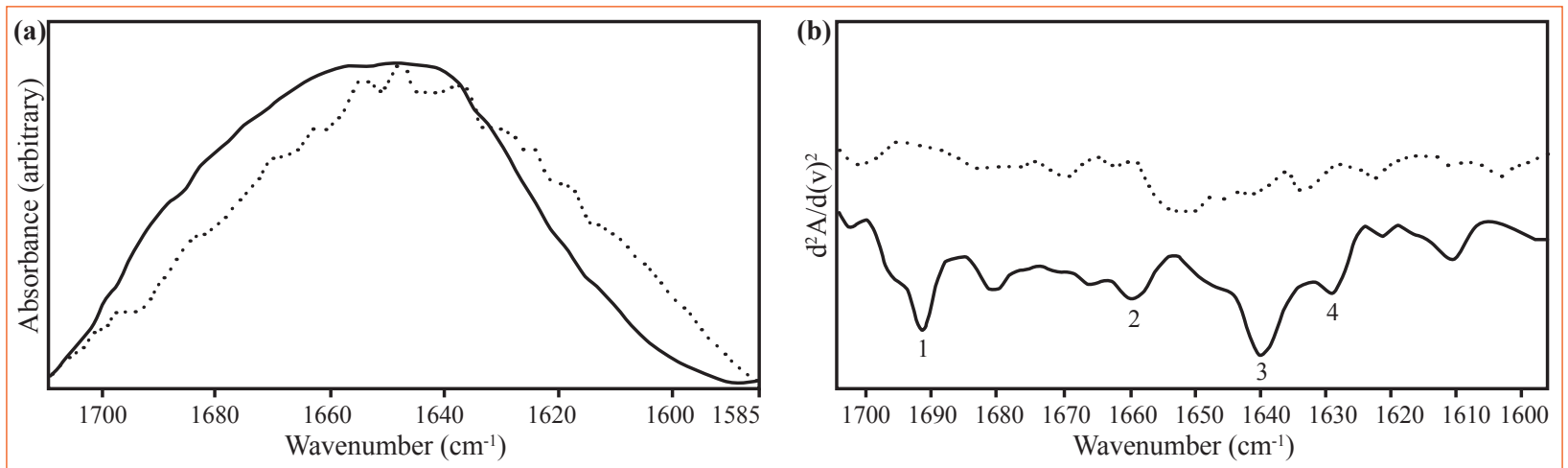

Figure 5. The average (a) absorbance and (b) second derivative spectra of original trypsin, trypsin in the supernatant of trypsin-E. arvense extract in 1700-1600 $\mathrm{cm}^{-1}$ region (continuous line shows original trypsin, dashed line shows trypsin in trypsin-E. arevense extract).

2004 Maliar et al. [28] concluded that flavonoids could be used as potential trypsin inhibitors due to their hydrophobic nature. They concluded that quercetin and apigenin were the most effective phenolics for the inhibition of trypsin enzyme activity [29]. In light of these findings and the knowledge of $E$. arvense's rich content of flavonoids and phenolic compounds [8] especially apigenin and quercetin, it is possible that these compounds can easily interact with the trypsin enzyme and cause to decrease the total percent activity. Moreover Hirano et al. (1992) [25] showed that plant materials in general could release amino acids into surrounding solution which could have inhibitory effects on trypsin enzyme as well. In our research $70 \%$ ethanol was used for extraction, during extraction procedure polypeptides could easily be transferred to aqueous solution. These amino acids can possibly interact with trypsin enzyme and cause enzyme inactivation. The conformational change of trypsin was irreversible as the nature of the assay in this research.

Silicic acid is the major inorganic substance in the plant's chemical composition. The investigations of this acid revealed that as the $\mathrm{pH}$ of the environment reached to the proteins isoelectric points, proteins interact with silicic acid by possible adsorption to form complexes called amine silicate via their histidine and amino groups [30].

\section{FTIR analyses}

FTIR analyses were carried out to study the effect of the interaction between the extract and trypsin on the structure of the extract. The spectra were analyzed in 3720$2800 \mathrm{~cm}^{-1}$ and $1780-1500 \mathrm{~cm}^{-1}$ regions. The results are shown in Figure 4.

The FTIR studies indicated significant changes in the protein structures and lipid partitioning in the process. Since trypsin concentration kept at a lower level, the spectra obtained represent only the signals originating from the extract material. The spectra were analyzed in two different spectral frames: $3720-2800 \mathrm{~cm}^{-1}$ regions and $1780-1500$ $\mathrm{cm}^{-1}$ region. As seen in Figure 4 a, the interaction between trypsin and the extract affects the structure-composition of the extract components. Since the spectral region between 3720 and $3000 \mathrm{~cm}^{-1}$ corresponds to amide-A region stemming from proteins both the band shifting and the shapes of the amide A bands indicate both structural-compositional changes in proteins and also possible changes in the hydrogen bonding network in the proteins or between the proteins and the other extract materials. In the same figure the region between $3000 \mathrm{~cm}^{-1}$ and $2800 \mathrm{~cm}^{-1}$ were heavily dominated by bands originating from lipids. A striking feature of the spectra was that the lipid signals came mostly from insoluble pellets (insoluble part of the precipitate formed after enzyme extract interaction) indicating the accumulating of lipids originating from the plant material in the insoluble pellet part. The same features of the materials were also observed in Figure $4 \mathrm{~b}$. The increase in the Amide II band intensity around 1550 $\mathrm{cm}^{-1}$ indicates the increase in the hydrogen bond network as well in the insoluble pellet.

An FTIR analysis was carried out to understand the nature of the decrease in the enzymatic activity to be able to distinguish any possible denaturation from enzyme activity inhibition. For this purpose a spectral difference analysis was performed. Simply, we subtracted the spectrum of the supernatant samples from $E$. arvense extract spectrum and obtained the spectrum of trypsin in the mixture and then compared it with the original trypsin spectrum using normalization procedures. The spectra were quite different from each other as seen in Figure 5 a. The trypsin spectrum was found to lose many secondary structural components as opposed to the original trypsin spectrum (Figure $5 \mathrm{~b}$ ). The major sub bands that showed differences were that at $1694 \mathrm{~cm}^{-1}$ (1:antiparallel $\beta$-sheets), at 1658 $\mathrm{cm}^{-1}$ (2: $\alpha$-helix), at $1637 \mathrm{~cm}^{-1}$ (3: $\beta$-sheets), and at 1627 $\mathrm{cm}^{-1}$ (4:aggregated $\beta$-sheets) [31].

Therefore we concluded that the interaction between $E$. arvense extract and trypsin in the supernatant samples resulted in denaturation of trypsin.

\section{Phenolic content studies}

Literature reviews showed that phenolics had a capacity to 


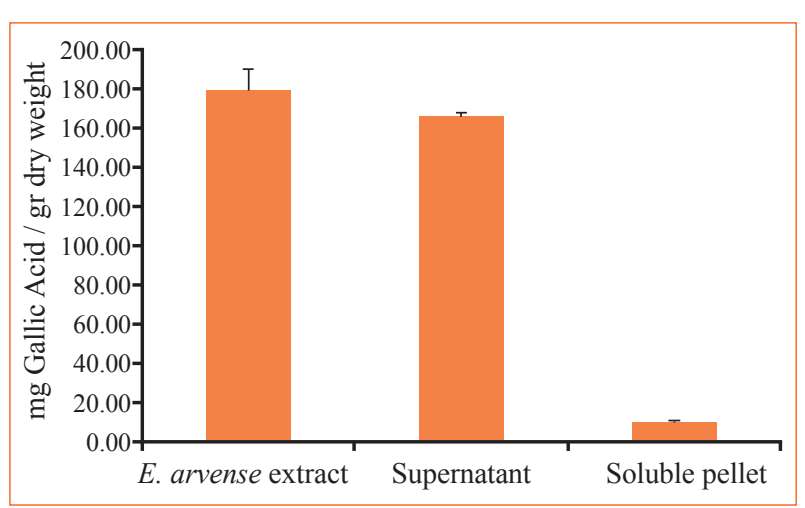

Figure 6. Total phenolic content of initial E. arvense extract, supernatant after $60 \mathrm{hr}$ treatment of extract with trypsin, soluble pellet of extract after $60 \mathrm{hr}$ treatment of trypsin.

interact and precipitate enzymes and proteins [24]. In this research a white precipitate was seen in all the samples of extracts treated with trypsin. Also the inhibition of enzymatic activity increased with the increasing concentration of the plant extract. In order to understand whether this inhibition occurs as a result of phenolics enzyme interaction or not, the total phenolic content of extracts before and after treatment with enzyme was analyzed and the results are presented in Figure 6.

Total phenolic content of the initial $E$. arvense extract, supernatant after $60 \mathrm{hr}$ treatment of extract with trypsin, and soluble pellet of the extract after $60 \mathrm{hr}$ treatment of trypsin are shown in Figure 6. Both of the supernatant and $E$. arvense sample are prepared from $1 \mathrm{mg} / \mathrm{ml}$ plant extract. As a result of this the total phenolic content is given as the milligram gallic acid equivalent/g. dry weight of extract. It is seen that when the total phenolic contents of the supernatant and the soluble pellet are considered they are equal to the phenolic content of $E$. arvense extract. Most of the phenolics remain in the supernatant and some are in the soluble precipitate phase reversibly. The high amount of phenolics in the supernatant would be the reason of trypsin inhibition. The phenolics could interact with proteins and force them to precipitate. Also the presence of

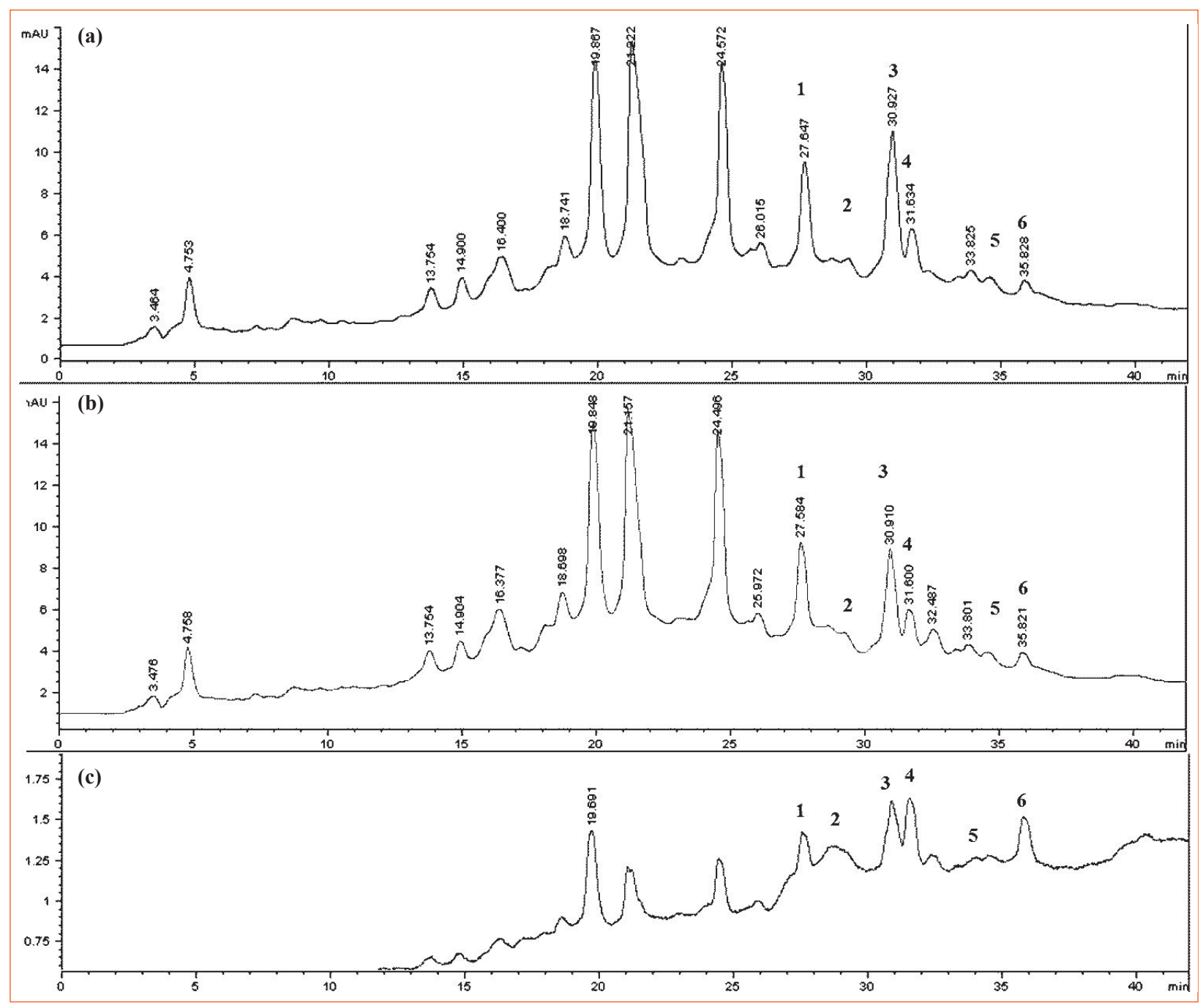

Figure 7. HPLC chromatograms of (a) the initial E. arvense extract, (b) supernatant after $60 \mathrm{hr}$ treatment of extract with trypsin and (c) soluble pellet of extract after $60 \mathrm{hr}$ treatment of trypsin at $280 \mathrm{~nm}$. 
Table 1. Change in the peak areas in HPLC chromatograms of initial E. arvense extract and supernatant after $60 \mathrm{hr}$ treatment of extract with trypsin and soluble pellet of extract treated $60 \mathrm{hr}$ with trypsin

\begin{tabular}{ccc}
\hline & \multicolumn{2}{c}{ Peak areas } \\
\cline { 2 - 3 } Peak number & E. arvense & Supernatant \\
\hline 1 & 546.9 & 517.14 \\
2 & 400.78 & 393.38 \\
3 & 515.35 & 400.64 \\
4 & 190.42 & 177.55 \\
5 & 148.6 & 122.58 \\
6 & 230.53 & 179.56 \\
\hline
\end{tabular}

phenolics in the soluble precipitate would be the evidence of interaction of phenolic compounds with proteins.

\section{HPLC analysis}

In order to confirm the previous results HPLC analyzes of the initial E. arvense extract, supernatant after treatment of extract with trypsin, soluble pellet of extract after treatment of trypsin is performed. The peak areas are determined and the differences are reported as shown in Figure 7.

In Figure 7, the HPLC chromatograms of initial E. arvense extract, supernatant after $60 \mathrm{hr}$ treatment of extract with trypsin, soluble pellet of extract after $60 \mathrm{hr}$ treatment of trypsin are shown. When the peak areas are analyzed it was seen that there is a decrease in the amounts of compounds found in the apolar region of the chromatograms upon precipitation. The amount of compounds labeled on the chromatogram from 1 to 6 changes between $E$. arvense extract and supernatant. The amount of decrease is shown on Table 1. The peaks of corresponding number could be seen on the chromatogram of the soluble pellet. As a result of protein phenolic interaction precipitation occurs. According to HPLC results of supernatant, it can be seen that there is a decrease in the phenolic content of E. arvense after treating with trypsin. Those findings are strong proofs for protein phenolic compound interaction.

Due to use of $E$. arvense as an alternative medicinal plant and its proven antioxidant, antimicrobial and anti-inflammatory effects, the effects of $E$. arvense extract on trypsin enzyme is investigated in this study. According to the enzyme kinetic assay, enzyme inhibition assay and FTIR analyses; it is seen that $E$. arvense extract has an inhibitory effect on trypsin activity. In addition, the interaction with trypin causes the extract material to precipitate out. This interaction resulted in accumulation of the extract lipids in the insoluble precipitate phase. As a result of the FTIR findings we concluded that the inhibitory effect of plant extract on trypsin enzyme was due to denaturation of enzyme. Also the enzyme kinetic analyses on both pellet form and supernatant form showed that the denaturation after interaction between $E$. arvense extract and trypsin was irreversible. In addition it was observed that the interaction between the extract and trypsin caused protein precipitation. As a conclusion, the interaction between the extract and trypsin is due to enzyme denaturation.

Antitrypsin compounds are used in agriculture as pesticides, in food industry [32,33]. Therefore $E$. arvense extract can be used as a potential antitrypsin compound.

\section{Acknowledgements}

We thank to the İzmir Institute of Technology, Biotechnology and Bioengineering central Research Laboratories for their help and cooperation. Trypsin was purchased with funds from IYTE Scientific Research Council (BAP) with the project numbers 2008IYTE22.

\section{Conflict of Interest}

There are no conflicts of interest among the authors.

\section{References}

[1] Li HB, Wong CC, Cheng KW, Chen F. Antioxidant properties in vitro and total phenolic contents in methanol extracts from medicinal plants. LWT - Food Sci Technol 2008; 41:385-390.

[2] Karl JS, Troukhanova NV, Lynn PY. Nature of polyphenol-protein interactions. J Agr Food Chem 1996; 44:80-5.

[3] Hagerman AE, Rice ME, Ritchard NT. Mechanisms of protein precipitation for two tannins, pentagalloyl glucose and epicatechin16 (4f8) catechin (Procyanidin). J Agr Food Chem 1998; 46:2590-5.

[4] Bartolomé B, Estrella I, Hernández MT. Interaction of low molecular weight phenolics with proteins (BSA). J Food Sci 2000; 65:617-21.

[5] Briskin DP. Medicinal plants and phytomedicines. Linking plant biochemistry and physiology to human health. Plant Physiol 2000; 124(2):507-14.

[6] Milovanović V, Radulović N, Todorović Z, Stanković M, Stojanović G. Antioxidant, antimicrobial and genotoxicity screening of hydro-alcoholic extracts of five serbian Equisetum species. Plant Foods Hum Nutr 2007; 62(3):113-9.

[7] Stajner D, Popović BM, Canadanović-Brunet J, Anackov G. Exploring Equisetum arvense L., Equisetum ramosissimum L. and Equisetum telmateia L. as sources of natural antioxidants. Phytother Res 2009; 23(4):546-50.

[8] Mimica-Dukic N, Simin N, Cvejic J, Jovin E, Orcic D, et al. Phenolic compounds in field horsetail (Equisetum arvense L.) as natural antioxidants. Molecules 2008; 13(7):1455-64.

[9] Sandhu NS, Kaur S, Chopra D. Equisetum arvense: Pharmacology and phytochemistry - a review Asian. J Pharm Clin Res 2010; 3:146-50.

[10] Do Monte FH, dos Santos JG Jr, Russi M, Lanziotti VM, Leal LK, et al. Antinociceptive and anti-inflammatory properties of the hydroalcoholic extract of stems from Equisetum arvense L. in mice. Pharmacol Res 2004; 49(3):239-43.

[11] Milovanović V, Radulović N, Todorović Z, Stanković M, Stojanović G. Antioxidant, antimicrobial and genotoxicity screening of hydro-alcoholic extracts of five serbian Equisetum species. Plant Foods Hum Nutr 2007; 62(3):113-9.

[12] Radulović N, Stojanović G, Palić R. Composition and antimicrobial activity of Equisetum arvense L. essential oil. Phytother Res 2006; 20(1):85-8.

[13] Canadanovic'-Brunet JM, Cetkovic' GS, Djilas SM, Tumbas VT, Savatovic' SS, et al. Radical scavenging and antimicrobial activ- 
ity of horsetail (Equisetum arvense L.) extracts. Int. J Food Sc1 Tech 2009; 44(2):69-278.

[14] Tepkeeva II, Moiseeva EV, Chaadaeva AV, Zhavoronkova EV, Kessler YV, et al. Evaluation of antitumor activity of peptide extracts from medicinal plants on the model of transplanted breast cancer in CBRB-Rb(8.17)1Iem mice. Bull Exp Biol Med 2008; 145(4):464-6.

[15] Alexandru V, Petrusca DN, Gille E. Investigation of pro-apoptotic activity of Equisetum arvense 1. Water extract on human leukemia u 937 cells. Rom Biotech Lett 2007; 12:3139-48.

[16] Hayat A, Temamogullari F, Yilmaz R, Karabulut O. Effect of Equisetum arvense on wound contraction of full-thicknes skin wounds in rabbits. J Anim Vet Adv 2011; 10:81-3.

[17] Rackis JJ. Significance of soya trypsin inhibitors in nutrition. JAOCS 1981; 58:495-501.

[18] Liener IE. Trypsin inhibitors: concern for human nutrition or not? J Nutr 1986; 116(5):920-3.

[19] Zhang Y, Yue Y, Li J, Chen X. Studies on the interaction of caffeic acid with human serum albumin in membrane mimetic environments. J Photochem Photobiol B 2008; 90(3):141-51.

[20] Arts MJ, Haenen GR, Voss HP, Bast A. Masking of antioxidant capacity by the interaction of flavonoids with protein. Food Chem Toxicol 2001; 39(8):787-91.

[21] Zhang HM, Zhou QH, Yang YQ, Wan YQ. Investigation of the Interaction between Rutin and Trypsin in Solution by Multi-Spectroscopic Method. Spectrosc Lett 2010; 43:183-91.

[22] Tiana J, Liua J, Tiana X, Hu Z, Chen X. Study of the interaction of kaempferol with bovine serum albumin. J Mol Struct 2004; 69:197-202.

[23] Schellman JA. Temperature, stability, and the hydrophobic interaction. Biophys J 1997; 73(6):2960-4.
[24] Rawel HM, Czajka D, Rohn S, Kroll J. Interactions of different phenolic acids and flavonoids with soy proteins. Int J Biol Macromol 2002; 30(3-4):137-50.

[25] Hirano H, Kagawa H, Okubo K. Characterization of proteins released from legume seeds in hot water. Phytochemistry 1992; 31(3):731-5.

[26] Duranti M, Barbiroli A, Scarafoni A, Tedeschi G, Morazzoni P. One-step purification of Kunitz soybean trypsin inhibitor. Protein Expr Purif 2003; 30(2):167-70.

[27] Parellada J, Guinea M. Flavonoid inhibitors of trypsin and leucine aminopeptidase: a proposed mathematical model for IC50 estimation. J Nat Prod 1995; 58(6):823-9.

[28] Maliar T, Jedinák A, Kadrabová J, Sturdík E. Structural aspects of flavonoids as trypsin inhibitors. Eur J Med Chem 2004; 39(3):241-8

[29] He Q, Lv Y, Yao K, Effects of tea polyphenols on the activities of $\alpha$-amylase, pepsin,trypsin and lipase. Food Chem 2006; 101:1178-82.

[30] Holt PF, Bowcott JE. The interaction of proteins with silicic acid. Biochem J 1954; 57(3):471-5.

[31] Baran Y, Ceylan C, Camgoz A. The roles of macromolecules in imatinib resistance of chronic myeloid leukemia cells by Fourier transform infrared spectroscopy. Biomed Pharmacother 2013; 67(3):221-7.

[32] Yeh KW, Lin MI, Tuan SJ, Chen YM, Lin CY, et al. Sweet Potato (Ipomoea batatas) Trypsin Inhibitors Expressed in Transgenic Tobacco Plants Confer Resistance Against Spodoptera litura. Plant Cell Rep 1997; 16:696-9.

[33] Shahidi F, Kamil YVAJ. Enzymes from Fish and Aquatic invertebrates and their application in the food industry. Trends Food Sci Tech 2001; 12:435-64. 